\title{
Study of a Cantilevered Magnetic Actuator with a Magnetic Thin Film
}

\author{
C. Yokota, A. Yamazaki, M. Sendoh*, S. Agatsuma, K. Morooka, K. Ishiyama, and K. I. Arai \\ Research Institute of Electrical Communication, Tohoku University, 2-1-1 Katahira, Aoba-ku, Sendai 980-8577, Japan \\ *Miyagi Organization For Industry Promotion, 1-14-2 Kamisugi, Aoba-ku, Sendai 980-0011, Japan
}

\begin{abstract}
This paper describes a cantilevered magnetic actuator driven in a low magnetic field. Magnetostriction was used as a driving principle in this study. We studied the displacement of the cantilevered magnetic actuator by the magnetostriction. FeSiB with the thickness of $0.7 \mu \mathrm{m}$ was used as a magnetostrictive thin film. The dimensions of the cantilever were $1 \mathrm{~mm} \times 5 \mathrm{~mm}$. We used polyimide films with thicknesses of $30 \mu \mathrm{m}$ and $7.5 \mu \mathrm{m}$ and Ni foil with a thickness of $5 \mu \mathrm{m}$ as substrates. As a result, the cantilevered magnetic actuator was able to function in a magnetic field of $10 \mathrm{kA} / \mathrm{m}$. The maximum displacement of the cantilevered magnetic actuator was about $40 \mu \mathrm{m}$ with an $\mathrm{Ni}$ substrate.
\end{abstract}

Key words: cantilever, FeSiB, magnetostriction, magnetic thin film, soft magnetic

\section{磁性薄膜を用いた片持ち梁型磁気アクチュエータに関する検討}

\author{
横田周子・山崎彩・仙道雅彦*・我妻成人・師岡ケイ子・石山和志・荒井賢一 \\ 東北大学電気通信研究所, 仙台市青葉区片平 2-1-1（率980-8577） \\ "みやぎ産業振興機構，仙台市青葉区上杉 1-14-2（テ980-0011）
}

\section{1. はじめに}

片持ち梁型アクチュエータは長尺試料片側を固定し反対 側の自由端を変位させるものであり, その駆動方式には圧 電型 ${ }^{1)}$, 熱膨張型 ${ }^{2}$, 磁歪型 ${ }^{3)}$ 等が挙げられる. それぞれの 駆動方式にはそれぞれの利点があり，それぞれの特徴を利 用した検討が行われている. 圧電型や熱膨張型は変位量が 多いものの絶縁層などが必要性であり構造が複雑になると いった問題点がある。これらに対し磁歪型は非接触駆動が 可能であることや，試料構造が簡単であるといった利点が 挙げられる.

我々は磁歪型を用いた研究において，10 $10^{-4}$ 台の大きな磁 歪を有し圧電型等と同程度の変位が見込まれる非晶質の $\mathrm{Tb}-\mathrm{Fe}$ や Sm-Feを用いた片持ち梁型アクチュエータに関す る検討を行ってきた ${ }^{3)}$. しかしこのアクチュエータは結晶 質の巨大磁歪材料を用いた場合に比べて小さな磁界で動作 するものの, $80 \mathrm{kA} / \mathrm{m}$ 程度の磁界印加が必要であった。 ま た $10 \mathrm{kA} / \mathrm{m}$ 以下の磁界中ではヒステリシスが現れ，アクチ ユエータの変位量が磁界強度に対して一意に決まらないな ど実用上の問題点もあった。

そこで本研究では磁界強度 $10 \mathrm{kA} / \mathrm{m}$ 以下で駆動可能な片 持ち梁型アクチュエータに関する検討を行った。ここでは 磁歪材料として磁歪定数が $10^{-6}$ 台と小さいものの軟磁気 特性の良好な FeSiB を用い, 弱磁界中で変位量をより大き く得る事を目的とし異方性制御ならびに基板選択について の検討を行った. その際, 変位量を求める理論式を導出し, 実験結果と対比してアクチュエータとしての性能を評価し た.

\section{2. 片持ち梁型アクチュエータ}

\section{1 駆動原理}

磁歪材料は内部の磁化方向の変化に伴って微小に寸法変 化する特性を持つ.ここで使用する $\mathrm{FeSiB}$ は正磁歪材料で あるため，印加磁界の方向に伸び，印加磁界に垂直方向に 縮む。これに，印加磁界に対し $\mathrm{FeSiB}$ の伸縮特性とは異な る伸縮特性を持つ材料を貼付し，2 層構造とすることによ り磁歪駆動による片持ち梁型アクチュエータを作成した.

Fig. 1(a)に外観図を示す.

この試料を駆動させる際，印加磁界方向を試料長手方向 とすると変位の増大と共に磁気トルクの影響を受け, 変位 が妨げられる。そこで本検討では印加磁界方向を試料幅方 向とし，アクチュエータの先端の変位量を検討した. Fig. 1(b)に外部磁界の印加により変位するアクチュエータの外 観図を示す。

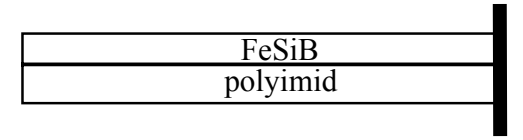

(a) Side view of the actuator.

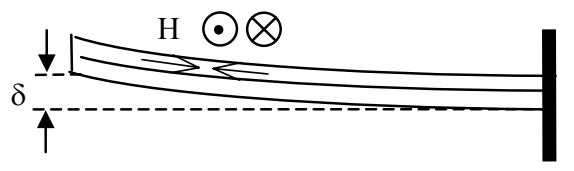

(b) Displacement by magnetostriction.

Fig. 1 Configuration and displacement of the magnetic actuator. 


\section{2 試料作成，及び測定方法}

2 層構造から成るアクチュエータの薄膜部分の成膜には $\mathrm{RF}$ スパッタ装置を用いた。 ターゲット組成は $\mathrm{Fe}_{72} \mathrm{Si}_{14} \mathrm{~B}_{14}$ とし, Power $200 \mathrm{~W}, \mathrm{Ar}$ ガス圧 $24 \mathrm{mTorr}$ ，スパッタ時間 1 時間で行った.この条件下で薄膜厚さは約 $0.7 \mu \mathrm{m}$ となっ た. 成膜された磁性膜を幅 $1 \mathrm{~mm}$, 長さ $5 \mathrm{~mm}$ になるよう に基板ごと切り出し, 片持ち梁型構造を形成した. 最後に 異方性制御を目的として熱処理を行った. 熱処理条件は温 度 $350^{\circ} \mathrm{C}$, 磁界強度 $240 \mathrm{kA} / \mathrm{m}$ とし, 回転速度 $60 \mathrm{rpm}$ の回 転磁界中熱処理を 2 時間, その後静磁界中熱処理を 1 時間 とした.

作成した試料の磁気特性は, VSM を用いて測定した.ア クチュエータの先端変位量の測定は, 片側を固定した試料 を磁界発生用コイル内に置き, 試料幅方向に磁界を印加し て変位させ試料先端の変位量をマイクロスコープにより実 測することで行った.

本実験では試料の異方性の方向，基板厚さ，基板材料を 変化させ，それらの条件がアクチュエータの変位特性に及 ぼす影響を検討した。 なお，本研究で基板に用いたフィル ム, フォイルは市販の製品である. Fig. 2 に実際にポリイ ミドフィルムを用いて作成した試料の写真を示す.

\section{3. 理論式}

駆動源に磁歪を用いた片持ち梁型アクチュエータの変位量を求 める理論計算 4) 5) としてこれまで様々なものが示されてい る.これらは試料形状等に依存した個々の近似による理論式で あるため，そのまま本研究に適用することはできない。こ こでは我々が今回実験をしていく上で, 検討の基淮とするため に導出した理論式を Fig. 3 のように寸法を定めて示す.

アクチュエータには試料全体が変位をしても, 元の状態 と長さが変化しない面が存在し, これを中立面と呼び Fig. 3 に記される一点鎖線部分になる.この面は理論式を導出 する上で重要なパラメータとなり，試料内部で中立面に関 して上下の力のつりあいが零という条件により求まる。一

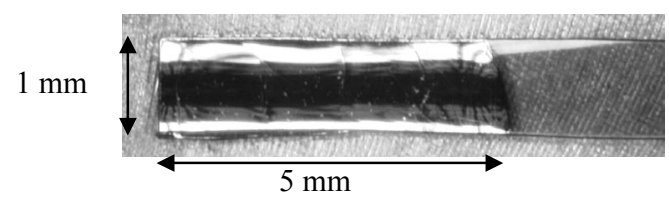

Fig. 2 Picture of the magnetic actuator.

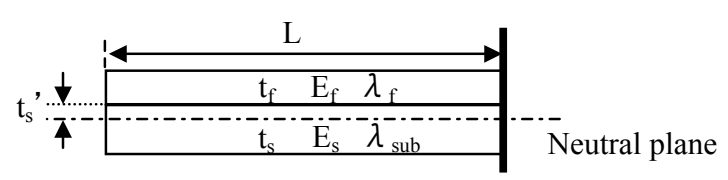

Fig. 3 Structure of the cantilevered magnetic actuator and neutral plane.
般に中立面の位置は，二層構造の貼付面からの長さで定義

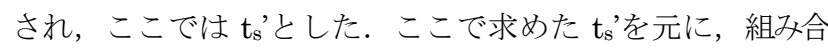
わせ梁において全長で曲げモーメントは一様, 試料長さに対して 変位角が微小という二つの仮定条件 6)を用いて片持ち梁アクチュ エータの先端変位の理論式を導出した.

$t_{s}^{\prime}=\frac{E_{s} t_{s}^{2}-E_{f} t_{f}^{2}}{2\left(E_{s} t_{s}-E_{f} t_{f}\right)}$

$$
\left.\left.\delta=\frac{3 L^{2}\left\{E_{s} \lambda_{s u b} t_{s}\left(-t_{s}+2 t_{s}{ }^{\prime}\right)+E_{f} \lambda_{f} t_{f}\left(t_{f}+2 t_{s}{ }^{\prime}\right)\right\}}{4\left\{E_{s} t_{s}\left(t_{s}{ }^{2}-3 t_{s} t_{s}{ }^{\prime}+3 t_{s}{ }^{\prime 2}\right)+E_{f} t_{f}\left(t_{f}{ }^{2}+3 t_{f} t_{s}{ }^{\prime}+3 t_{s}{ }^{\prime 2}\right)\right.}\right)\right\}
$$

この時計算に用いた主な記号は， $\delta$ : 自由端先端の変位 量, $\mathrm{L}$ ：試料長さ, $\mathrm{w}$ : 試料幅, $\mathrm{t}_{\mathrm{f}}$ ：磁性薄膜の厚さ, $\mathrm{E}_{\mathrm{f}}$ ：磁 性薄膜のヤング率, $\lambda_{\mathrm{f}}$ : 磁性薄膜の磁歪值, $\mathrm{t}_{\mathrm{s}}$ : 基板材料 の厚さ, $\mathrm{E}_{\mathrm{s}}$ ：基板材料のヤング率， $\lambda \mathrm{sub}$ ：基板材料の磁歪 值, $\mathrm{t}_{\mathrm{s}}{ }^{\prime}$ : 薄膜と基板の貼り合わせ部分から中立軸までの厚 さ，とした，導出された理論式により，アクチュエータの変位量 を増加させるための適正な薄膜や基板の材料特性，厚さ等が予測 可能となる. 本研究では薄膜材料, ならびにその厚さは変化させ ず，基板厚さと基板材料の影響についての検討を行った.

\section{4. 実験結果}

\section{1 異方性制御}

試料作成の際に行う異方性制御の方向についての検討を行っ た. 磁歪により大きな変位を得るためには, 磁気モーメントの 回転が必要である 7)．前述のように本実験では試料幅方向 に磁界を印加することから，その際に磁気モーメントの回 転量を多くするためには長手方向に容易軸を誘導すべきで あると考えられる．この考えを元に本検討では容易軸方向 を試料長手方向，試料幅方向それぞれにつけた試料を作成 し, 異方性の方向亡変位特性の関連について検討を行った. 基板には厚さ $30 \mu \mathrm{m}$ のポリイミドフィルムを用い, 異方性 の方向は磁界中熱処理により誘導した．Fig. 4 に異方性方 向を 90 度変化させたそれぞれの試料幅方向の磁気特性を 示す。またこれらの試料の磁界と変位の関係を Fig. 5 に示 す.これらの結果から磁歪材料 $\mathrm{FeSiB}$ を用いた片持ち梁型 アクチュエータが $10 \mathrm{kA} / \mathrm{m}$ 以下の小さな磁界で十分に駆動 できること, ヒステリシスの小さい変位特性が実現できた ことがわかる、また，試料長手方向に容易軸方向を制御す ることにより磁界に対する応答性が良好となり, 変位量も 容易軸方向が試料幅方向の場合には $6 \mu \mathrm{m}$ であるのに対し, 試料長手方向の場合には $9 \mu \mathrm{m}$ まで増加することが明らか となった。

\section{2 基板厚さ}

変位量を増加させる方法の一つとして, 変位力となる磁歪材料 の量を増やすことが考えられる．しかし磁歪材料を厚くすること は同時に変位を妨げる機械的負荷を増加させることにもなる．そ 
のため試料作成の際には，発生力，試料強度等を考慮し基板と薄 膜の厚さの関係を適切にすることが大切となる.これは先に述心゙ た理論式からも理解される。ここでは磁歪薄膜の厚さを 0.7 $\mu \mathrm{m}$ と一定条件とし, 適切な基板厚さについての検討を行 った. 基板には厚さ $30 \mu \mathrm{m}$ ならびに $7.5 \mu \mathrm{m}$ のポリイミド フィルムを用いた。なお異方性制御については 4.1 節の実 験結果を踏まえ共に試料長手方向が容易軸方向となるよう 制御した．Fig. 6 に基板厚さを変化させたそれぞれの試料 幅方向の磁気特性を示す。試料は試料長手方向に異方性を 制御するよう同条件の下で作成したが，その磁気特性には 差が表れた。これは基板厚さを変化させることによって, 試料作成後の薄膜と基板の間に残る残留応力に違いが生じ たことに起因すると考えられる．

この様な磁気特性を持つ試料の磁界と変位の関係を Fig. 7 に示寸. 同図より $10 \mathrm{kA} / \mathrm{m}$ の磁界印加において, ポリイ ミドフィルムの厚さが $30 \mu \mathrm{m}$ の場合変位量が $9 \mu \mathrm{m}$ であっ たのに対し，厚さが $7.5 \mu \mathrm{m}$ の場合では $30 \mu \mathrm{m}$ もの変位量 となった.これより薄膜厚さ $0.7 \mu \mathrm{m}$ に対ポリイミドフィル

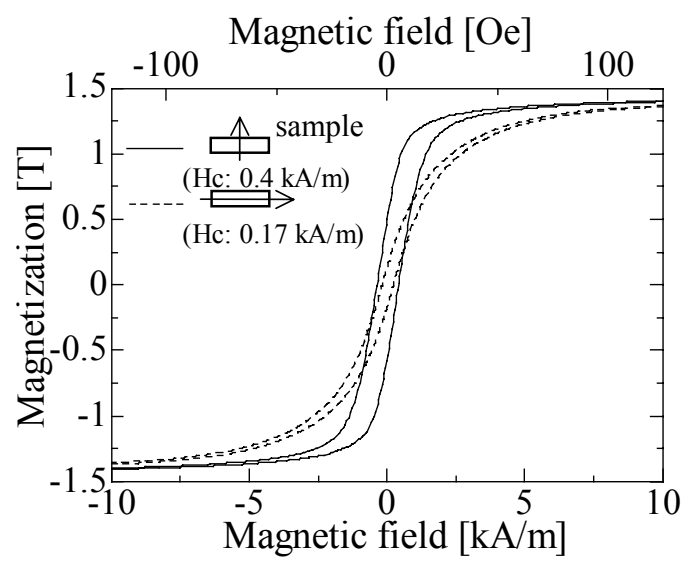

Fig. 4 Magnetic property in the width direction of the cantilevered magnetic actuators.

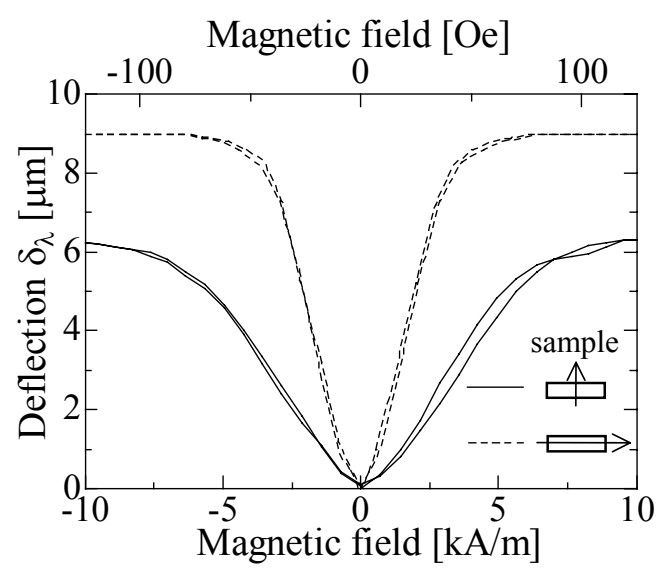

Fig. 5 Relation between the magnetic field and the displacement, $\delta_{\lambda}$, caused by magneostriction.

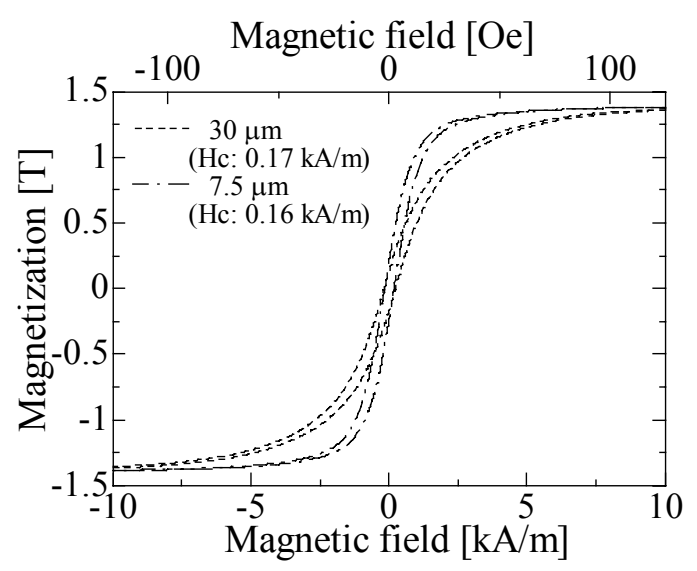

Fig. 6 Magnetic property in the width direction of the cantilevered magnetic actuators.

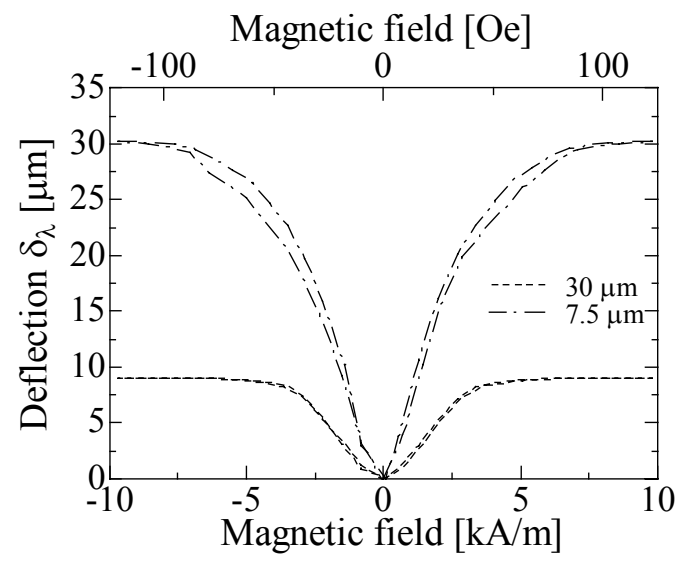

Fig. 7 Relation between the magnetic field and the displacement, $\delta_{\lambda}$, caused by magnetostriction.

ムを用いた場合，基板厚さ $30 \mu \mathrm{m} よ り ~ 7.5 \mu \mathrm{m}$ と薄くした 方が適切であることがわかる。両者の磁気特性は Fig. 6 に 示されるように差はあるが，ここでは磁界強度 $10 \mathrm{kA} / \mathrm{m}$ 印 加時の変位特性であることから，両者の基板厚さの影響が 表れたものと考えられる.

\section{3 基板材料}

基板材料選択についての検討結果について示す。ここでは非磁 性のポリイミドフィルムに代えて，負磁歪材料である Ni を用いて検討を行った. 正磁歪材料である $\mathrm{Fe}_{72} \mathrm{Si}_{14} \mathrm{~B}_{14}$ を成 膜する基板として負磁歪材料である $\mathrm{Ni}$ フォイルを用いる ことで，片持ち梁をバイモルフ構造にできる．このためポ リイミド基板を用いたユニモルフ構造に比べて大きな変位 が期待される.ここでは基板として厚さ $7.5 \mu \mathrm{m}$ のポリイミ ドフィルム，厚さ $5 \mu \mathrm{m}$ の $\mathrm{Ni}$ フォイルの 2 種類を用いた. なお異方性制御については 4.2 節と同様に試料長手方向が 容易軸方向となるよう制御した。

Fig. 8 にポリイミドフィルム、Ni フォイルを基板とした それぞれの試料幅方向の磁気特性を示す. Fig. 9 にこれら の試料の磁界と変位の関係をそれぞれ示す. Fig. 9 に示さ 


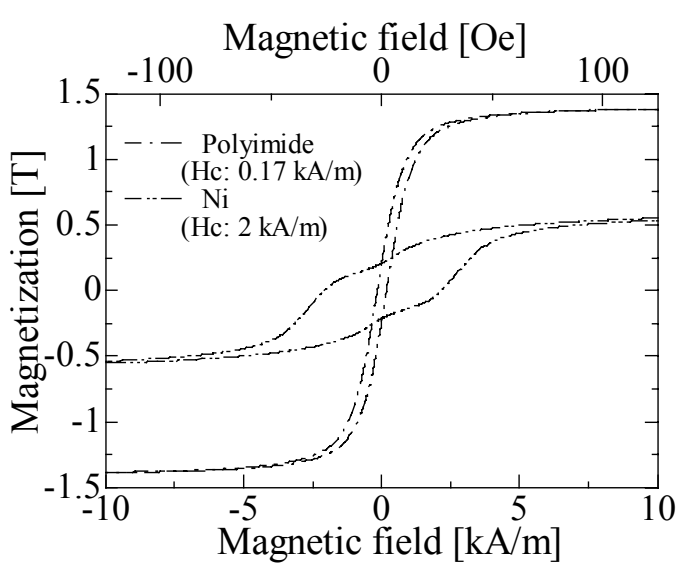

Fig. 8 Magnetic property in the width direction of the cantilevered magnetic actuators.

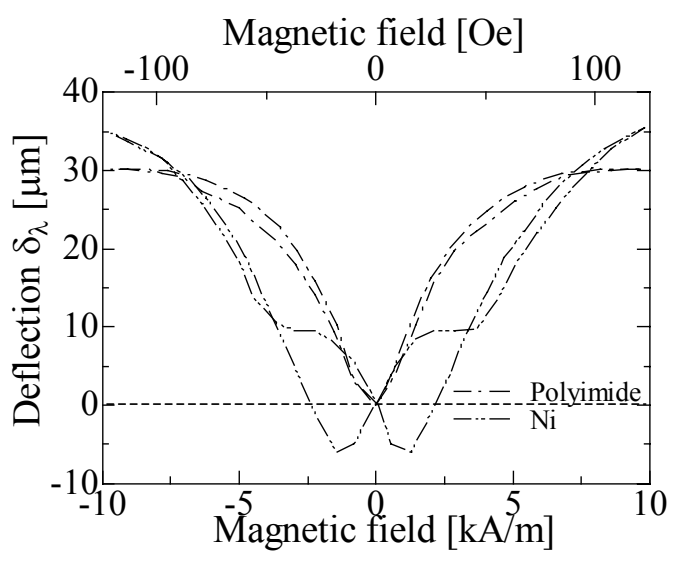

Fig. 9 Relation between the magnetic field and displacement, $\delta_{\lambda}$, caused by magnetostriction.

れるように基板に $\mathrm{Ni}$ フォイルを使用した場合, 変位する過 程において弱磁界中でヒステリシスが生じた。 このヒステ リシスの原因は, Fig. 8 に示される磁気特性から明確なよ うに $\mathrm{Ni}$ フォイルが $2 \mathrm{kA} / \mathrm{m}$ の保磁力を持つためであると考 えられる。しかしこの影響は実験を行った磁界強度 10 $\mathrm{kA} / \mathrm{m}$ に対して小さな磁界範囲内であり, 最大印加磁界にお けるアクチュエータの変位量には影響しないと考えられ る. 変位量は基板にポリイミドフィルムを使用した場合に $30 \mu \mathrm{m}$ であったのに対し， Ni フォイルを使用した場合で は $40 \mu \mathrm{m}$ もの変位量が得られた。

\section{4 実験值之理論値の比較}

以上検討に用いた試料における実験值と，先述した理論 式より求められる理論值を比較する。ここで理論式を用い る際には, 次の二点を考慮した. 第一に磁界印加方向と磁 歪観測方向が直交していることから，理論值を算出する際 の磁歪の值を磁歪定数 $\lambda$ の $-1 / 2$ とした ${ }^{8}$. 第二にこの磁歪 材料の磁気特性より求めた磁界強度 $10 \mathrm{kA} / \mathrm{m}$ での磁化量 $\mathrm{M}$ の飽和磁化量 Ms に対する比 $\mathrm{M} / \mathrm{Ms}$ を先ほど求めたー $\lambda / 2$ に乗じた值を磁歪量として計算式に代入した。 その他の機
Table 1 Calculated and experimental values for the displacement of the cantilevered magnetic actuator.

\begin{tabular}{|c|c|c|c|}
\hline Magnetic thin film $(\mathrm{f})$ & FeSiB & FeSiB & FeSiB \\
\hline Substrate $(\mathrm{s})$ & Polyimide & Polyimide & $\mathrm{Ni}$ \\
\hline Thickness of $(\mathrm{f}) \mathrm{t}_{\mathrm{f}}(\mu \mathrm{m})$ & 0.7 & 0.7 & 0.7 \\
\hline Thickness of $(\mathrm{s}) \mathrm{t}_{\mathrm{s}}(\mu \mathrm{m})$ & 30 & 7.5 & 5 \\
\hline Calculated value $(\mu \mathrm{m})$ & 8 & 34 & 41 \\
\hline Experimental value $(\mu \mathrm{m})$ & 9 & 30 & 40 \\
\hline
\end{tabular}

械定数等は次の值を用いた。 $\mathrm{L}: 5 \mathrm{~mm}, \mathrm{w}: 1 \mathrm{~mm}, \mathrm{tf}_{\mathrm{f}}: 0.7$ $\mu \mathrm{m}, \mathrm{E}_{\mathrm{f}}: 210 \mathrm{GPa}, \lambda_{\mathrm{f}}:-15 \times 10^{-6}$ (磁歪定数: $35 \times 10^{-6}$, $\mathrm{M} / \mathrm{Ms}=0.86$ ), 基板にポリイミドフィルムを用いた場合には $\mathrm{E}_{\mathrm{s}}: 3.5 \mathrm{Gpa}$, 基板に $\mathrm{Ni}$ フォイルを用いた場合には $\mathrm{E}_{\mathrm{s}}: 210$ Gpa, $\lambda_{\text {sub }}: 14 \times 10^{-6}$ (磁歪定数: $-33 \times 10^{-6}, \mathrm{M} / \mathrm{Ms}=0.85$ ) 計算結果と実感結果をまとめたものが Table 1 である. この表よりアクチュエータの変位量は, 理論式とほぼ同程 度の実験結果が得られた事がわかる。この結果前述した理 論式の妥当性が示され，今後変位量の増加に向けて検討を していく際の基準として用い，基板等の最適化を行ってい $<$.

\section{5. まとめ}

磁歪材料である $\mathrm{Fe}_{72} \mathrm{Si}_{14} \mathrm{~B}_{14}$ 薄膜を用いた片持ち梁型アク チュエータの駆動に関する検討を行った. 実験の結果, 磁 界強度 $10 \mathrm{kA} / \mathrm{m}$ 以下で駆動可能な片持ち梁型磁気アクチュ エータの実現と共に, 弱磁界中における変位量として従来 の検討結果に比べてより大きな変位量が得られた。また， 異方性制御や基板選択によりアクチュエータとしての変位 を増加させることができ, 最大約 $40 \mu \mathrm{m}$ の変位が得られた. 今後片持ち梁型アクチュエータの更なる駆動磁界の減少, 変位量の増加を目的として検討を行っていく。

\section{References}

1) M. Okugawa, Y. Hori: Transactions of the Japan Society of Mechanical Engineers, 69, 858 (2003).

2) O. Nakabeppu, T. Kanda: IEEJ transactions on sensaors and micromachines, 124, 75 (2004).

3) K. I. Arai, T. Honda: J. Jpn. Soc. Prec. Eng., 60, 1699 (1994).

4) T. Honda, K. I. Arai: J. Magn. Soc. Jpn., 21, 817 (1997).

5) A. C. Tam and H.Schroeder: J. Appl. Phys., 64, 5422 (1988).

6) Y. Takahashi, S. Machida: Kisozairyourikigaku (in Japanese), p.131 (Baihu-kan, Tokyo, 1988).

7) Institute of electrical engineers magnetics technical committee: Magnetic-Fundamentals and Application (in Japanese), p.33 (Korona-sya, Tokyo, 1999).

8) Institute of electrical engineers magnetics technical committee: Magnetic-Fundamentals and Application (in Japanese), p.34 (Korona-sya, Tokyo, 1999).

2005年10月19日受理，2005年12月19日再受理，2006年1月16日採録 